\title{
Challenges and progresses of energy storage technology and its application in power systems
}

\author{
Liangzhong YAO ${ }^{1}$, Bo YANG ${ }^{1}$, Hongfen CUI ${ }^{1}$, Jun ZHUANG ${ }^{\mathbf{1}}$, \\ Jilei YE ${ }^{1}$, Jinhua $\mathrm{XUE}^{1}$
}

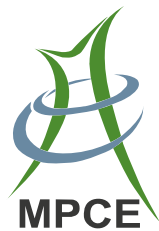

\begin{abstract}
As a flexible power source, energy storage has many potential applications in renewable energy generation grid integration, power transmission and distribution, distributed generation, micro grid and ancillary services such as frequency regulation, etc. In this paper, the latest energy storage technology profile is analyzed and summarized, in terms of technology maturity, efficiency, scale, lifespan, cost and applications, taking into consideration their impact on the whole power system, including generation, transmission, distribution and utilization. The application scenarios of energy storage technologies are reviewed and investigated, and global and Chinese potential markets for energy storage applications are described. The challenges of large-scale energy storage application in power systems are presented from the aspect of technical
\end{abstract}

CrossCheck date: 27 September 2016

Received: 19 September 2016/Accepted: 27 September 2016/ Published online: 19 October 2016

(C) The Author(s) 2016. This article is published with open access at Springerlink.com

$\triangle$ Hongfen CUI

cuihongfen@epri.sgcc.com.cn

Liangzhong YAO

yaoliangzhong@epri.sgcc.com.cn

Bo YANG

yangbo@epri.sgcc.com.cn

Jun ZHUANG

zhuangjun@epri.sgcc.com.cn

Jilei YE

yejilei@epri.sgcc.com.cn

Jinhua XUE

xuejinhua@epri.sgcc.com.cn

1 China Electric Power Research Institute, Nanjing 210003, Jiangsu, China and economic considerations. Meanwhile the development prospect of global energy storage market is forecasted, and application prospect of energy storage is analyzed.

Keywords Renewable energy, Energy storage technology, Energy storage application, Power system

\section{Introduction}

In order to establish a sustainable energy system and overcome energy and environmental crisis caused by the utilization of fossil fuels, a new energy revolution is taking shape in that with electricity as the central form of energy. It is characterized with the development and utilization of large-scale renewable energy. With the development of smart grid, supported by investment and government policies, the prospect of energy storage application are gradually emerging [1-5]. Its potential applications could be found in the entire spectrum of power systems such as generation, transmission, distribution and utilization. These applications include increasing penetration level of largescale renewable energy, improving power grid's efficiency, postponing and reducing construction cost of generation and power systems, improving power quality and energy efficiency, ensuring a high-quality, safe, realizable power supply, promoting the optimization of grid planning, scheduling management and operation control [6-10].

The development and commercialization of energy storage technology will have a significant impact on power system in terms of future system model [11]. In recent years, both engineering and academic research have grown at a rapid pace, which lead to many achievements. Due to rapid development of energy storage technology, the research and demonstration of energy storage are expanding from small-scale towards large-scale. United States, 
Japan, the European Union have proposed a series of policies for applications of energy storage technology to promote and support industrial development [12-16]. Chinese government is also paying attention to the development of energy storage technology, from strategic planning to demonstration projects, and the related policies associated with energy storage application value and potential markets are shown on the aspects of China's energy, electric power, science research, transportation, environmental protection and so forth.

So far main energy storage technologies have reached commercial or demonstration level all over the world, the developed technologies include pumped storage, compressed air, flywheel, lead acid batteries, lithium ion batteries, sodium sulfur batteries, flow battery, super capacitors and superconducting magnetic energy storage, etc. [17-24]. Furthermore, with fast development of material science, researches on new energy storage technologies such as graphen based energy storage technologies, are also carried out. References [25-27] presented the overviews of energy storage technologies for electric power applications. In terms of scale up application in energy storage at present, hundreds of MW level energy storage demonstration projects have been built worldwide [28-32]. The demonstration projects cover renewable energy grid integration, distributed generation, microgrid, transmission, distribution and frequency regulation. In the future, after gaining clearer understanding of the role and impact of energy storage technologies on the energy system, their application field and technology roadmap are expected to be the focus globally.

In this paper, the energy storage technology profiles, application scenarios, implementation status, challenges and development prospects are reviewed and analyzed, which provides a useful reference to the future energy storage technology development in terms of electricity market, investment decision and policy formulation.

\section{Current status of energy storage technology development}

According to the way of energy stored, the energy storage technology can be classified into five major categories, i.e. mechanical energy storage, heat-energy storage, electrochemical energy storage, magnetic energy storage and chemical energy storage [33].

\section{1) Mechanical energy storage}

The mechanical energy storage technologies mainly include the pumped storage, compressed-air energy storage and flywheel energy storage. The pumped storage is the most mature technology, which is characterized with having large capacity, long service lifespan and low unit cost. However, the construction of the pumped storage power station is restricted by geographical conditions, the construction period is longer, and the overall investment is large. The compressed-air energy storage has the advantages of large capacity, long operation time, long service lifespan, etc. And also it is capable of supplying combined heat, cold, and electricity by converting the compressed-air into other alternative energy. However its efficiency is low, the system is complex, and the location requirement for the air storage mine tunnel is high $[34,35]$. The flywheel energy storage has the advantages of high efficiency, fast response, long service lifespan, less demands on operation and maintenance, good stability, short construction period, small footprint and no pollution, but the energy density is low, easy to be self-discharge which is only suitable for short time applications [36, 37]. The comparative analysis of various types of mechanical energy storage technologies is shown in Table 1.

\section{2) Heat storage}

Heat storage technologies are categorized into sensible heat storage and latent heat storage. The sensible heat storage can achieve the purpose of heat storage by increasing the temperature of the heat storage material, generally uses the water as the heat storage medium. The latent heat storage uses the regenerative material achieving phase change heat storage, which is implemented on the solar thermal power generation. The heat storage system in the photothermal system can provide the heat energy needed or generate electricity when the solar radiation is insufficient in rainy days for example. Therefore the output of electricity from heat storage system can be adjusted according to the grid operation requirement $[38,39]$. The energy storage efficiency of the thermal storage system can reach $95 \%-97 \%$ [40], and the cost is only about $1 / 30$ of the large-scale battery storage. Molten salt storage technology is currently a research hotspot which is applied to the concentrated solar thermal power plant. It has the advantages of low cost, high heat capacity and safety, etc. It has been commercialized in developed countries such as Spain, Italy and other parts of Europe and North America. However the problems in its practical application are still very prominent, in which corrosive characteristic is one of its shortcomings. In addition the molten salt solidification temperature is high, and easy to cause equipment scrapped.

\section{3) Electrochemical energy storage}

Electrochemical energy storage technologies include lead-acid battery, lithium-ion battery, sodium-sulfur battery, redox flow battery. Traditional lead-acid battery technology is well-developed and has the advantages of low cost and easy maintenance. But because available 
Table 1 Comparative analysis on various types of mechanical energy storage technologies

\begin{tabular}{|c|c|c|c|c|c|c|c|}
\hline Category & & $\begin{array}{l}\text { Technology } \\
\text { maturity }\end{array}$ & $\begin{array}{l}\text { Efficiency } \\
(\%)\end{array}$ & $\begin{array}{l}\text { Power rate } \\
\text { (MW) }\end{array}$ & $\begin{array}{l}\text { Service life } \\
\text { (year) }\end{array}$ & Cost $(¥ / k W)$ & Application \\
\hline Pump storage & & Commercial & $70-80$ & 1000 & $40-50$ & $3500-4000$ & $\begin{array}{l}\text { Peak load regulation, frequency regulation, } \\
\text { phase shift, reverse, black start }\end{array}$ \\
\hline \multirow{2}{*}{ Air-compressed } & Conventional & Commercial & $48-52$ & $5-300$ & $30-50$ & $6500-7000$ & \multirow{2}{*}{$\begin{array}{l}\text { Peak load regulation, reverse, } \\
\text { grid-connected renewable energy }\end{array}$} \\
\hline & $\overline{\text { Supercritical }}$ & Demonstration & $52-65$ & $1.5-100$ & $30-50$ & $6500-7000$ & \\
\hline $\begin{array}{l}\text { Flywheel energy } \\
\text { storage }\end{array}$ & & Commercial & $>95$ & $0-20$ & 20 & $1700-2000$ & $\begin{array}{l}\text { Frequency regulation auxiliary service, } \\
\text { power quality, enterprise UPS }\end{array}$ \\
\hline
\end{tabular}

capacity decreases under deep, fast and high power discharge, there are shortcomings such as low energy density, lower life expectancy, environmental pollution, etc [41, 42]. In recent years, Japan, United States and other countries are committed to develop more advanced leadacid battery, and there have developed several types of batteries including lead-carbon battery, super battery and so on.

Currently, the lithium ion batteries have many applications in power industry, including lithium iron phosphate battery, lithium titanate battery and nickel-cobalt-manganese lithium battery. Lithium iron phosphate has advantages of better stability, security and longer cycle life. Although the cost of lithium titanate battery is relative high, it has high security, long life cycle, good charge/ discharge characteristics, which may became future development direction of lithium ion battery. Nickelcobalt-manganese lithium batteries has relative high energy and power density, but high price and limited the cobalt resources constrains large-scale manufacture of nickelcobalt-manganese lithium battery.

Redox flow battery mainly includes vanadium redox flow battery, zinc bromine flow battery. The vanadium redox flow battery has long lifespan and high life cycle, but has disadvantages of low energy and power density, slow response. Zinc bromine flow battery has advantage of high energy density, low cost and frequent deep discharge, but it also has the problem of high self-discharge rate caused by electrode reaction producing complex.

Sodium sulfur battery has advantages of high energy density, good power characteristics, and long cycle life and so on. It has become well-developed MW level electrochemical energy storage technology, and has realized commercial operation. However, it uses the flammable metal sodium material, and operates in high temperature $\left(300-350^{\circ} \mathrm{C}\right)$ conditions, which poses an issue of safety risk. The comparative analysis of various types of electrochemical energy storage technologies is shown in Table 2.

\section{4) Electromagnetic energy storage}

The electromagnetic energy storage mainly contains super capacitor and superconducting magnetic energy storage. Super capacitor has advantages of high power density, fast response, high efficiency, long cycle life, low maintenance, wide operational temperature range and so on. However, due to the low energy density, super capacitor is suitable for application in combination with other energy storage technologies [43, 44]. The charging/discharging rate of superconducting magnetic energy storage is critical, and it has advantages of high power density, fast response, high energy conversion efficiency, long service lifespan, etc. It is suitable for high power requirement. But there are many disadvantages such as high cost, low energy density and complex maintenance [45]. The comparative analysis of electromagnetic energy storage technology is shown in Table 3.

\section{5) Chemical energy storage}

Chemical energy storage is considered as a secondary energy carrier using hydrogen or synthetic gas, of which hydrogen is electrolyzed, and it can also be synthetized into natural gas (i.e. methane) with carbon dioxide. This green technology without any pollution could lead to formation of large-scale energy storage which can store more than $100 \mathrm{GWh}$ energy. However it has problems of low energy conversion efficiency which is only $40 \%-50 \%$, high cost, large investment and low security [46]. At present, hydrogen energy storage technology has also been demonstrated in many countries [46]. Fuel cell is the main way of hydrogen utilization. Proton Exchange Membrane (PEM) fuel cell is widely used in electric power, thermal power, transportation and other industries, performs as the backup power source and improves the utilization of renewable energy generation. Currently the main aim for its application is to improve its cost, efficiency and lifespan, leading to a prospect of better renewable energy utilization and large-scale hydrogen as the fundamental energy system. 
Table 2 Comparative analysis on various types of electrochemical energy storage technologies

\begin{tabular}{|c|c|c|c|c|c|c|c|}
\hline Category & & $\begin{array}{l}\text { Technology } \\
\text { maturity }\end{array}$ & $\begin{array}{l}\text { Efficiency } \\
(\%)\end{array}$ & $\begin{array}{l}\text { Power } \\
\text { rate } \\
(\mathrm{MW})\end{array}$ & $\begin{array}{l}\text { Service } \\
\text { life } \\
\text { (year) }\end{array}$ & Cost $(¥ / \mathrm{kW})$ & Application \\
\hline \multirow{2}{*}{$\begin{array}{l}\text { Lead-acid } \\
\text { battery }\end{array}$} & $\begin{array}{l}\text { Traditional lead-acid } \\
\text { battery }\end{array}$ & Commercial & $70-85$ & $0-20$ & 5 & $500-1000$ & $\begin{array}{l}\text { Transportation, communication, } \\
\text { national defense, aviation, etc }\end{array}$ \\
\hline & Lead-carbon battery & Demonstration & $70-85$ & $0-20$ & $5-8$ & $6400-10400$ & $\begin{array}{l}\text { Peak load shifting, reserve } \\
\text { power supply, etc }\end{array}$ \\
\hline \multirow{3}{*}{$\begin{array}{l}\text { Lithiumion } \\
\text { battery }\end{array}$} & $\begin{array}{l}\text { Lithium iron } \\
\text { phosphate battery }\end{array}$ & $\begin{array}{l}\text { Demonstration } \\
\text { Commercial }\end{array}$ & $90-95$ & $0-32$ & 8 & $3200-5800$ & \multirow{3}{*}{$\begin{array}{l}\text { All aspects of generation, } \\
\text { transmission, distribution and use, } \\
\text { including stabilizing renewable } \\
\text { energy output, frequency regulation } \\
\text { auxiliary service, peak load } \\
\text { regulation, power battery }\end{array}$} \\
\hline & $\begin{array}{l}\text { Lithium titanate } \\
\text { battery }\end{array}$ & $\begin{array}{l}\text { Demonstration } \\
\text { Commercial }\end{array}$ & $>95$ & $0-32$ & 10 & 9000 & \\
\hline & $\begin{array}{l}\text { Nickel-cobalt-mang } \\
\text { anese lithium } \\
\text { battery }\end{array}$ & $\begin{array}{l}\text { Demonstration } \\
\text { Commercial }\end{array}$ & $>95$ & $0-32$ & 8 & $4000-5000$ & \\
\hline \multirow{2}{*}{$\begin{array}{l}\text { Redox flow } \\
\text { battery }\end{array}$} & $\begin{array}{l}\text { Vanadium redox } \\
\text { flow battery }\end{array}$ & Demonstration & $75-85$ & $0.03-10$ & 15 & $17500-19500$ & $\begin{array}{l}\text { Peak load regulation、 large-scale } \\
\text { grid-connected renewable energy, } \\
\text { UPS, emergency power supply, etc }\end{array}$ \\
\hline & $\begin{array}{r}\text { Zinc bromine } \\
\text { flow battery }\end{array}$ & Demonstration & $75-80$ & $0.05-2$ & 10 & $12500-15000$ & The user side \\
\hline $\begin{array}{l}\text { Sodium sulfur } \\
\text { battery }\end{array}$ & & Commercial & 87 & $0-50$ & 15 & $13200-13800$ & $\begin{array}{l}\text { Load regulation, peak load shifting, } \\
\text { large-scale grid-connected renewable } \\
\text { energy, power quality, etc }\end{array}$ \\
\hline
\end{tabular}

\section{Application scenarios of energy storages in power systems}

The energy storage technology is a breakthrough to electrical "generation" and "use up" simultaneously which is the feature of conventional electrical energy technology, and it is adequate for various application fields, including renewable energy grid integration, power transmission and distribution, distributed generation, microgrid and frequency regulation, etc [28, 32, 47-49]. As a flexible power source, energy storage can be widely implemented and applied in power generation, transmission, distribution and utilization. The application scenario of energy storage can be divided into five types described below.

\subsection{Renewable energy generation}

Due to the fluctuating and intermittent characteristics of wind and solar power generation, the problems associated with integrating renewable energy and managing power system stability are becoming more and more prominent. Meanwhile, the severe impacts caused by large power system incidents highlight the urgent demand for high-efficiency, large-scale energy storage technology. Therefore, through the application of energy storage, redundant wind and solar power can be stored and power grid is in turn to be able to provide more stable power output, which provides fast support to the active power, enhances the capability of grid frequency regulation, and leads to large-scale wind and solar generation connecting to grid both stable and reliable. Therefore, energy storage technology has become one of central tools for integrating renewable energy generation with power grid.

\subsection{Transmission and distribution}

With vigorous development of wind and solar power generation, it is difficult to realize complete absorption of renewable energy because of insufficient flexible resources and transmission corridor. Meanwhile, with the increase of wind and solar power penetration in power system, the intermittency and fluctuation will inevitably cause a volatility, high uncertainty and complexity in renewable energy generation, and will require more flexible resources for frequency regulation, load tracking and base-load supply. Moreover, renewable energy generation does not have the capability of stabilizing the power system disturbance. The integration of renewable energy generation will definitely affect the reliability and operational stability of power system. The application of energy storage technology in power system can postpone the upgrade of transmission and distribution systems, relieve the transmission line congestion, and solve the issues of power system security, stability and reliability.

\subsection{Distributed generation and microgrid}

To maintain stable voltage and frequency of microgrid in different operational modes, microgrid has adopted with reasonable distributed generations and energy storage configuration in order to realize the transformation in different operational modes. During entry and exit of 
Table 3 Comparative analysis on various types of electromagnetic energy storage technologies

\begin{tabular}{|c|c|c|c|c|c|c|}
\hline Category & $\begin{array}{l}\text { Technology } \\
\text { maturity }\end{array}$ & $\begin{array}{l}\text { Efficiency } \\
(\%)\end{array}$ & Scale & $\begin{array}{l}\text { Service } \\
\text { life (year) }\end{array}$ & $\begin{array}{l}\text { Cost (¥/ } \\
\mathrm{kW})\end{array}$ & Application \\
\hline Super capacitor & Demonstration & $>90$ & 0-10 MW & 15 & $400-500$ & $\begin{array}{l}\text { Distributed generation and } \\
\text { microgrid }\end{array}$ \\
\hline Superconducting energy storage & Demonstration & $>95$ & 10-100 MJ & 30 & $6500-7000$ & $\begin{array}{l}\text { Power quality, system stability, } \\
\text { low frequency oscillation }\end{array}$ \\
\hline
\end{tabular}

distributed generations, the power is out of balance in a short time, the energy storage facility can be applied to realize fast charging/discharging control, and active power is able to be controlled smoothly and instantaneously to guarantee the voltage stability of significant load. In addition, the output power of both wind and solar power generations in microgrid is significant uncertainty, loads also change randomly. With the application of energy storage, the system dynamic balance can be maintained through adjusting the energy storage.

\subsection{End user}

\section{1) Large-user}

Centralized large-user has large load demand. In order to reduce electricity costs, the energy can be stored in the valley period and used for production and operation in the peak period, which can reduce the investment of power supply equipment and improve energy utilization efficiency.

\section{2) Household-user}

The energy storage technology can be applied as emergency power management system of household-users. It can adjust output power in coordination with solar generation while the electricity price is relatively high or load demand reaches to peak, so as to guarantee emergency power supply and reduce the load demand at peak period, and provide full energy for the family life. Household solar power storage systems have been realized and promoted in European and American countries.

\section{3) Vehicle to Grid, V2G}

The electric vehicle is able to be used as the energy storage unit connecting with power system. In this case the vehicle becomes a standby power source. Based on the interaction of electric vehicles and power system, it can realize the functions of peak-shift and frequency regulation.

\subsection{Ancillary services}

In order to fully develop and apply the energy storage technology, it is necessary to explore the application prospects of ancillary service market for energy storage. The ancillary services include peak-shifting, frequency regulation, fast start reserve, power quality and black start, etc. The energy storage can be used for rapidly frequency regulation services, and it has shown the application potential in this field.

\section{Energy storage application status}

\subsection{Global energy storage application status}

By the end of 2015, The applications of energy storage technology are distributed in all aspects of power systems [28, 32]. Figures 1 and 2 illustrate cumulative installed energy storage distribution according to applications and types, respectively. In the field of global energy storage demonstration projects, the energy storage is most widely applied for the grid-connected renewable energy projects, and the cumulative installed capacity accounted for $43 \%$. In recent years, this proportion is showing gradual reduction. The application of sodium sulfur battery is the most widely applied technology, and the installed capacity accounts for $58 \%$. The installed capacity of sodium sulfur battery has reached 338.9 MW worldwide, accounted for $36 \%$, which is only next to lithium ion battery. The core technology of sodium sulfur battery has been mastered by NGK. The domestic research in sodium sulfur battery is carried out very early. However the progress is relatively slow.

In recent years, cumulative installed capacity of energy storage with the fastest growth is in the area of frequency regulation service, where the energy storage accounts for up to $23 \%$. The United States has the largest installed capacity, frequency regulation market and commercial projects. The lithium ion battery and flywheel energy storage are the most widely implemented technologies, the proportion of total installed capacity has reached up to $78 \%$, and the lithium enterprises such as BYD, A123 System, LG Chem have deployed the most applications in this respect.

The energy storage system has been seen less applications in power transmission and distribution than the areas mentioned above. However it is still an important area of energy storage application. Especially in some countries or regions, 
along with vigorous development of renewable energy, and also for weak power system and aging electric facilities, energy storage is paid more and more attention. Sodium sulfur battery and lithium ion battery energy storage technologies are most widely used in this field, the proportion of cumulative installed capacity accounted for $81 \%$.

The energy storage applications in distributed generation and microgrid fields have the smallest proportion, account for $13 \%$. The lithium-ion battery and lead acid battery are the main energy storage technologies in this application, where the total installed capacity accounts for up to $77 \%$. The relative projects are demonstrated in the fields of island, industrial/commercial, household/community, rural region and solar power-storage power charging station for electric vehicle, etc, where the industrial and commercial energy storage applications have the largest proportion.

\subsection{Energy storage application in China}

By the end of 2015, the cumulative installed energy storage capacity in China is $105.5 \mathrm{MW}$, which is about $11 \%$ of global installed energy storage [28, 32, 50]. Figures 3 and 4 illustrate the installed capacity distribution based on application and storage type, respectively. In terms of application, the installed capacity of energy storage in China is different from other countries, and energy storage applications in distributed generation and microgrid field account for $56 \%$. Among them, lithium ion batteries and lead acid batteries are two of the most widely used technologies, and reach up to $89 \%$ in total. Energy storage projects are mainly implemented in island and remote areas, business areas and electric vehicles.

The installed capacity in grid-connected renewable energy field accounts for 35\%, next to the applications in distributed generation and microgrid. Most of them are lithium ion battery and redox flow battery energy storage, and the total installed capacity weights up to $94 \%$. The other type is the redox flow battery, and its installed capacity reaches 13MW. Energy storage demonstration projects such as National wind-solar-storage-transmission project, Meiyaoshan wind farm project and Woniushi wind farm project are representative. The application of Lithium ion battery has the largest proportion in the scenarios of grid-connected renewable energy, distributed generation and microgrid. The proportion is about $87 \%$ of the entire lithium-ion battery energy storage project.

There are only few domestic energy storage projects in power transmission and distribution, in which lithium ion batteries are used, such as the application at Baoqing power station, Meizhou island energy storage power station. Currently, domestic applications are relatively few in this field, and it is expected that the govenment will develop more energy storage projects in the power distribution system in the future.

At present, very few projects are installed and operated for frequency regulation service and account for $1 \%$ of installed capacity, and it has entirely employed the lithium-ion battery. Only two projects are successfully put into operation by Ray Power Company in the power grid of North China, and both of them participate in frequency regulation service in combination with thermal power plant.

\section{Challenges and prospects of energy storage technologies}

\subsection{Challenges of energy storage application}

The energy storage technology has promising application prospect in renewable energy generation grid integration, distributed generation, microgrid, transmission and distribution, smart grid and ancillary services. In [51], the 2050 development scenario in China is simulated, which shows that the energy storage demand will be between 560 and $780 \mathrm{GW}$. Meanwhile the electricity demand will attain between 2 and 3 billion $\mathrm{kWh}$ without considering grid constraints among regions in China. However, the large scale application of energy storage technology still faces challenges both in the technical and economic aspects.

\subsubsection{Technology challenges}

First of all, the development of energy storage technology requires the innovation and breakthrough in capacity, long-lifespan, low-cost, high-security for electrochemical energy storage. And also, physical storage technology with high-efficiency, low-cost is required. Secondly, the research should be focused on the energy storage simulation and operation optimization in multiple applications, which can support the application of energy storage technology from theoretical viewpoint, and develop demonstration projects and comprehensive evaluation to promote the industrialization and commercialization of energy storage. At the same time it is necessary to establish a complete and rigorous professional cohesion, reasonable classification, transparency, openness and energy storage standards, which will provide strong support for research and development, production and application of energy storage, and promote the development of energy storage technology and related industries.

\subsubsection{Economic challenges}

Currently, energy storage industry in China is still facing with challenges of lack of policy support, high cost, 


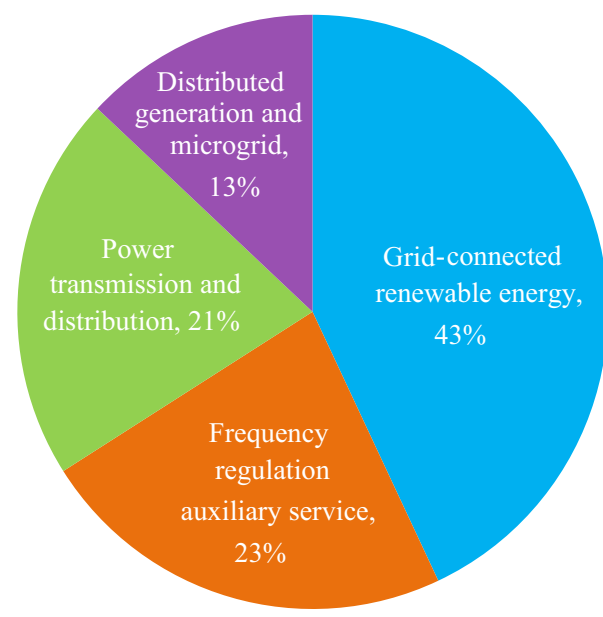

Fig. 1 Cumulative installation distribution of global energy storage for various applications

unclear application value, unhealthy market mechanism and other issues. Two aspects should be considered in the future: on the one hand, it is necessary to propose energy storage system solutions with the participations from electricity users, electrical enterprises, researcher, economical organizations and social originations, and on the other hand, the suitable industry market mechanism and the subsidy policy should be promoted. We should encourage numerous researches and applications of energy storage, establish a sustainable development model and achieve commercial operation of energy storage.

\subsection{Prospects of energy storage technology development}

VLPGO (twelve of the largest power grid operators) has launched an investigation into renewable energy development and energy storage planning in different countries. The United States, Japan, Spain, China and other countries

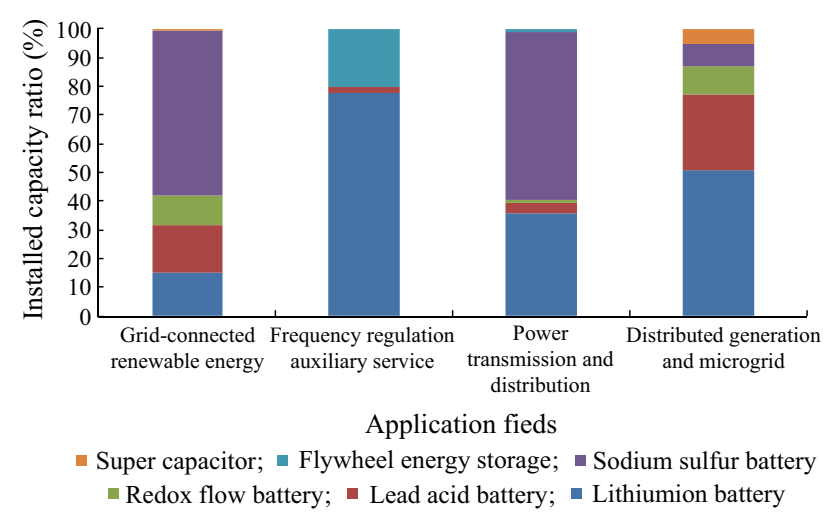

Fig. 2 Cumulative installation distribution of different types of energy storage on various applications globally have taken the wind, solar and other non-fossil fuels energy into consideration in the long-term energy planning. With the trends of rapid power system expansion and large-scale renewable energy development, each country has undertaken the grid planning for next 10-20 years taking into consideration the energy storage, and various types of energy storage technologies are evaluated and many demonstrations have been planned or built, which can vigorously promote the development and application of energy storage technology in the smart grid. According to the investigation results, energy storage is deployed as fast response product for frequency regulation service in many counties, and most power system companies are willing to purchase this service.

Electric Power Research Institute (EPRI) has classified and outlined fourteen categories for energy storage technology applications in power systems [52]. Energy storage has significant impacts on large-scale renewable energy grid integration, load shifting, postponing power grid constructions and improving power system security. These will also create a great opportunity for energy storage development at the same time. Based on the Woori conjecture [53], the value of global energy storage will increase by $26 \%$ annually in the future, the market value of global energy storage will be up to $\$ 16$ billion in 2020 . Even if the energy storage has many prospective markets, high cost, insufficient subsidy policy, indeterminate price mechanism and business model are still the key challenges.

From the application point of view, with the promotion of China's government, the development of energy internet will promote wide application of energy storage, and will be with rapid growth in installed capacity. Within the background of continuous promotion and application of electric vehicle, it will play a greater role in the energy internet architecture as it can be considered as mobile modular unit for energy storage. Although Chinese energy storage industry is still faced with problems such as lack of policy support, unclear technical specification, small scale, high cost, low value and unhealthy mechanism, etc, the rapid application development of future energy storage industry is a foregone conclusion due to its capability in increasing renewable energy penetration level and improving electric energy efficiency.

\section{Conclusion}

In this paper, the technology profile of global energy storage is analyzed and summarized, focusing on the application of energy storage technology. Application scenarios of energy storage technologies are reviewed, taking into consideration their impacts on power generation, 


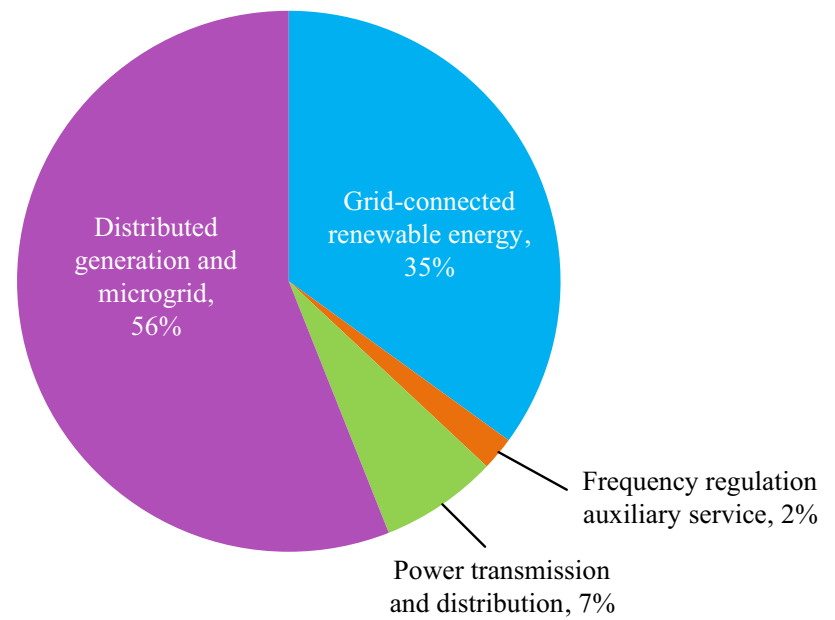

Fig. 3 Cumulative installation distribution of energy storage for various applications in China

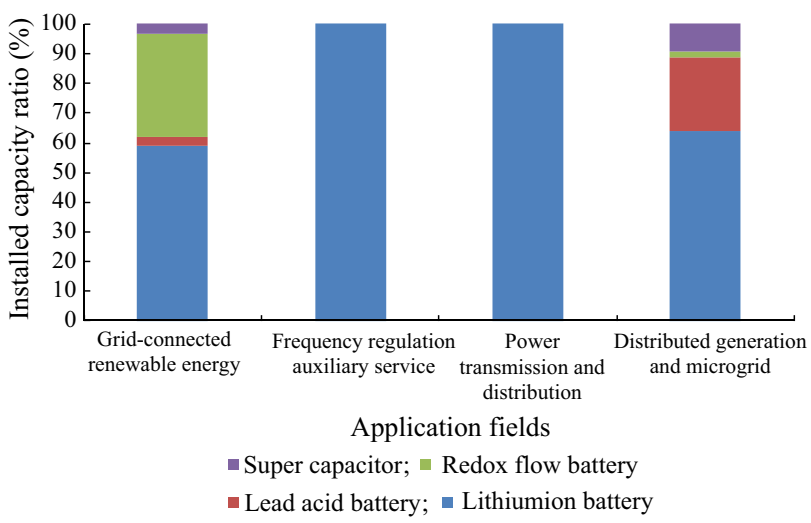

Fig. 4 Cumulative installation distribution of different types of energy storage for various applications in China

transmission, distribution and utilization. The general status in different applications is outlined and summarized. Ultimately, the challenges of scale-up application in energy storage and development prospect of future energy storage technology are expressed. The result indicates that, the energy storage has been widely applied in power systems connected with renewable energy generation. It also shows clear commercial benefit and prospect in the fields of peak shaving and frequency regulation of power systems, etc. The energy storage application in distributed generation and microgrid also keeps increasing, and it has shown great progress in the field of power transmission and distribution. The energy storage technology will play an important role in every stage, ensuring a safe, stable, economical operation of power systems, and it has broad application prospect. The development and expansion of energy storage technology not only depend on the improvement in storage characteristics, operational control and management strategy, but also requires the cost reduction and the supports from long-term, positive stable market and policy to guide and support the healthy development of energy storage industry.

Open Access This article is distributed under the terms of the Creative Commons Attribution 4.0 International License (http:// creativecommons.org/licenses/by/4.0/), which permits unrestricted use, distribution, and reproduction in any medium, provided you give appropriate credit to the original author(s) and the source, provide a link to the Creative Commons license, and indicate if changes were made.

\section{References}

[1] Consulting Group of State Grid Corporation of China to Prospects of New Technologies in Power systems (2013) An analysis of prospects for application of large-scale energy storage technology in power systems. Autom Electr Power Syst 37(1):3-8

[2] Hu J, Yang SL, Hou CY et al (2015) Present condition analysis on typical demonstration application of large-scale energy storage technology and its enlightenment. Power Syst Technol 39(4):879-885

[3] Li JL, Tian LT, Lai XK (2015) Outlook of electrical energy storage technologies under energy internet background. Autom Electr Power Syst 39(23):15-25. doi:10.7500/AEPS20150906004

[4] Wang CS, Wang D, Zhou Y (2015) Framework analysis and technical challenges to smart distribution system. Autom Electr Power Syst 39(9):2-9. doi:10.7500/AEPS20141202002

[5] Wang CS, Wu Z, Li P (2014) Prospects and challenges of distributed electricity storage technology. Autom Electr Power Syst 38(16):1-8. doi:10.7500/AEPS20140108002

[6] Lu QY, Hu W, Min Y et al (2015) A multi-pattern coordinated optimization strategy of wind power and energy storage system considering temporal dependence. Autom Electr Power Syst 39(2):6-12. doi:10.7500/AEPS20140922004

[7] Niu Y, Zhang F, Zhang H et al (2016) Optimal control strategy and capacity planning of hybrid energy storage system for improving AGC performance of thermal power units. Autom Electr Power Syst 40(10):38-45. doi:10.7500/AEPS20150724003

[8] Wang HJ, Jiang QY (2014) An overview of control and configuration of energy storage system used for wind power fluctuation mitigation. Autom Electr Power Syst 38(19):126-135. doi:10.7500/AEPS20140214008

[9] Yuan XM, Cheng SJ, Wen JY (2013) Prospects analysis of energy storage application in grid integration of large-scale wind power. Autom Electr Power Syst 37(1):14-18

[10] Liu WJ, Sun L, Lin ZZ et al (2015) Short-period restoration strategy in isolated electrical islands with intermittent energy sources, energy storage systems and electric vehicles. Autom Electr Power Syst 39(16):49-58. doi:10.7500/AEPS20141226008

[11] Zhou XX, Lu ZX, Liu YM et al (2014) Development models and key technologies of future grid in China. Proc CSEE 34(29):4999-5007

[12] US Department of Energy Office of Electricity Delivery \& Energy Reliability (2010) Electric power industry needs for grid-scale storage applications. http://www.doe.gov. Accessed date on 10 December 2010

[13] Dunn B, Kamath H, Tarascon JM (2011) Electrical energy storage for the grid: a battery of choices. Science 334(6058):928-935

[14] US Department of Energy Office of Electricity Delivery \& Energy Reliability (2011) Energy storage program planning 
document. http://www.doe.gov. Accessed date on 16 February 2011

[15] US Department of Energy Electricity Advisory Committee (2010) Bottling electricity: storage as an strategic tool for managing variability and capacity concerns in the modern grid. http://www.oe.energy.gov/eac.htm. Accessed date on 21 January 2010

[16] Luo X, Wang JH, Dooner M et al (2015) Overview of current development in electrical energy storage technologies and the application potential in power system operation. Appl Energy 137(C):511-536

[17] Cimuca GO, Saudemont C, Robyns B et al (2006) Control and performance evaluation of a flywheel energy storage system associated to a variable-speed wind generator. IEEE Trans Ind Electr 53(4):1074-1085

[18] Doria-Cerezo A (2013) Comments on "Control and Performance of a Doubly-Fed Induction Machine Intended for a Flywheel Energy Storage System". IEEE Trans Power Electr 28(1):605-606

[19] Zhu JH, Yuan WJ, Qiu M (2014) Experimental demonstration and application planning of high temperature superconducting energy storage system for renewable power grids. Appl Energy 137:692-698

[20] Oureilidis KO, Bakirtzis EA, Demoulias CS (2016) Frequencybased control of islanded microgrid with renewable energy sources and energy storage. J Modern Power Syst Clean Energy 4(1):54-62. doi:10.1007/s40565-015-0178-z

[21] Johnson MP, Bar-Noy A, Liu O et al (2011) Energy peak shaving with local storage[J]. Sustain Comp 1(3):177-188

[22] Wang ZM, Gu CH, Li FR et al (2013) Active demand response using shared energy storage for household energy management. IEEE Trans Smart Grid 4(4):1888-1897

[23] Cheng YZ, Tabrizi M, Sahni M et al (2014) Dynamic available AGC based approach for enhancing utility scale energy storage performance. IEEE Trans Smart Grid 5(2):1070-1078

[24] Xu GY, Xu L, Yao LZ (2013) Wind turbines output power smoothing using embedded energy storage systems. J Modern Power Syst Clean Energy 1(1):49-57. doi:10.1007/s40565-0130003-5

[25] Chen H, Cong TN, Yang W et al (2009) Progress in electrical energy storage system: A critical review. Progr Nat Sci 19(3):291-312

[26] Díaz-González F, Sumper A, Gomis-Bellmunt O et al (2012) A review of energy storage technologies for wind power applications. Renew Sustain Energy Rev 16(4):2154-2171

[27] Hadjipaschalis I, Poullikkas A, Efthimiou V (2009) Overview of current and future energy storage technologies for electric power applications. Renew sustain Energy Rev 13(6):1513-1522

[28] CNESA (2016) Energy storage industry research white paper. 2016

[29] Xu SP, Li XJ, Hui D (2013) A survey of the development and demonstration application of large-scale energy storage. Power Syst Clean Energy 29(8):94-100

[30] Xu XK, Bishop M, Oikarinen DG et al (2016) Application and modeling of battery energy storage in power systems. CSEE J Power Energy Syst 2(3):82-90

[31] IEC (2011) Electrical energy storage white paper. 2011, 12

[32] Zhang J (2016) Energy storage market inventory in 2015 and future prospects. China Electr Equip Ind 1:53-57

[33] Yu EK, Chen LJ (2011) Characteristics and comparison of largescale electric energy storage technologies. Zhejiang Electr Power 12:4-8

[34] Mei S, Wang J, Tian F et al (2015) Design and engineering implementation of non-supplementary fired compressed air energy storage system: TICC-500. Sci China Technol Sci 58(4):600-611
[35] Xue XD, Mei SW, Lin QY et al (2016) Energy inter-net oriented non-supplementary fired compressed air energy storage and prospective of application. Power Syst Technol 40(1):164-171

[36] Chen YA, Gan SL, Zhou JH et al (2016) Energy storage technology of flywheel. Chin J Power Sour 40(8):1718-1721

[37] Zhang XB, Chu JW, Li HL et al (2015) Key technologies of flywheel energy storage systems and current development status. Energy Storage Sci Technol 4(1):55-60

[38] Zahedi A (2014) Sustainable power supply using solar energy and wind power combined with energy storage. Energy Procedia 52:642-650

[39] Garcia IL, Alvarez JL, Blanco D (2011) Performance model for parabolic trough solar thermal power plants with thermal storage: comparison to operating plant data. Solar Energy 85(10):2443-2460

[40] Vick BD, Moss TA (2013) Adding concentrated solar power plants to wind farms to achieve a good ultility elcctrical load match. Solar Energy 92:298-312

[41] Jia LL, Liu P, Zhang WH (2014) Research progress of electrochemical technology of energy storage. Chin J Power Sour 40(8):1972-1974

[42] Xu SP, Li XJ, Hui D (2013) A review of development and demonstration application of large-scale electrochemical energy storage. Electr Power Constr 34(7):73-80

[43] Zhang XY, Zhang HZ, Lin ZQ et al (2016) Recent advances and challenges of stretchable supercapacitors based on carbon materials. Sci China Mater 59(6):475-494

[44] Béguin F, Presser V, Balducci A et al (2014) Carbons and electrolytes for advanced supercapcitors. Adv Mater 26(14):2219-2251

[45] Luo X, Wang J, Dooner M et al (2015) Overview of current development in electrical energy storage technologies and the application potential in power system operation. Appl Energy 137:511-536

[46] Huo XX, Wang J, Jiang L et al (2016) Review on key technologies and applications of hydrogen energy storage system. Energy Storage Sci Technol 5(2):197-203

[47] Tang XS (2016) Application and marketing mode of energy storages in power system. Electr Power Constr 8:2-7

[48] Yuan XM (2007) Integrating large wind farms into weak power grids with long transmission lines. Trans China Electrotech Soc 22(7):29-36

[49] Chen DY, Zhang LZ, Wang S et al (2013) Development of energy storage in frequency regulation market of United States and its enlightenment. Autom Electr Power Syst 37(1):9-13

[50] CICCAS (2016) The current situation and trend of "thirteenfive" of electrical energy storage industry, vol 6. China Electrical Equipment Industry, pp 24-27

[51] Bai JH, Xin SX, Liu J et al (2015) Roadmap of realizing the high penetration renewable energy in China. Proc CSEE 35(14):3699-3705

[52] EPRI (2010) Electricity energy storage technology option-A white paper primer on application, costs, and benefits. 2010

[53] Woori Investment and Securities. Industry Analysis Rechargeable Battery Industry. [S. 1.], 2011

Liangzhong YAO received his Ph.D. degree in Electrical Engineering from Tsinghua University, China, in 1993. He is a professor of Engineering and $\mathrm{PhD}$ tutor at China Electric Power Research Institute. His research interests are power system analysis, largescale wind farm grid integration and power electronics applications in power systems, etc.

Bo YANG receives his master degree from Southeast University. He is a senior engineer at China Electric Power Research Institute. His 
research interests are energy storage applications in power system and renewable energy generation technology.

Hongfen CUI receives her master degree in Power Engineering from North China Electric Power University, China. She is an engineer at China Electric Power Research Institute. Her research interests are flexible HVDC technology and distributed renewable energy gridconnecting technology, etc.

Jun ZHUANG receives his master degree in the school of Engineering Science from University of Southampton, UK, in 2010. $\mathrm{He}$ is an engineer at China Electric Power Research Institute. His research interests are power electronic converter technology and flexible HVDC technology.

Jilei YE receives her Ph.D. degree from Nanjing University, China. She is a senior engineer at China Electric Power Research Institute. Her research interest is energy storage technology and economy analysis in different applications.

Jinhua XUE receives her Ph.D. degree from Nanjing Tech University, China, in 2010. She is an engineer at China Electric Power Research Institute. Her research interest is energy storage capacity configuration technology in different applications. 